\title{
PENINGKATAN KEMAMPUAN KOMUNIKASI MATEMATIS \\ SISWA DENGAN MENGGUNAKAN MODEL PEMBELAJARAN \\ BERBASIS MASALAH DI KELAS X MAN 4 MARTUBUNG \\ MEDAN
}

\author{
Oleh: \\ Anugrah Mulia Tampubolon* \\ *Dosen Tetap STIT Al - Hikmah Tebing Tinggi \\ *Jalan Gatot Subroto KM. 3 Nomor 3 Kota Tebing Tinggi \\ e-mail: anugrah.tampubolon@gmail.com
}

\begin{abstract}
:
The purpose of this research was to identify the inprovement of student's communication ability as an impact of problem based learnin, asd to find the interaction between the instructional approach and gender with improvement of student's communication ability. This research wasa quasy experiment with the sample of research was 70 students, consisted of X-IPA ${ }^{2}$ with 35 students asan experiment class and X-IPA ${ }^{4}$ with 35 students as a control class. The data which collected in this research were communication ability. The instruments which used to collect the data were a test of communication ability. The data were analyzed by using two way anava in the SPSS program. Based on the result of this research, it could be concluded that the improvement student's communication ability by using problem based learning better than improvemet student's communication ability by using a usuall learning. There was not an interaction between the instructional approach and gender with improvement student's communication ability.
\end{abstract}

\section{Keywords:}

Problem Based Learning, Comunication Ability.

\section{A. Pendahuluan}

Pembelajaran secara sederhana dapat diartikan sebagai sebuah usaha memengaruhi emosi, intelektual, dan spiritual seseorang agar mau belajar dengan kehendaknya sendiri (Nata, 2009: 85). Seseorang tidak akan mau melakukan pembelajaran jika bukan atas kemauannya sendiri, artinya pembelajaran tidak dapat berlangsung dengan baik jika dilakukan dengan cara pemaksaan. Sedangkan menurut Sagala (2009: 62) pembelajaran sebagai proses belajar dibangun oleh guru untuk mengembangkan kreatifitas berfikir yang dapat meningkatkan kemampuan berfikir siswa yang dapat meningkatkan kemampuan mengkonstruksi pengetahuan baru sebagai upaya meningkatkan penguasaan yang baik terhadap materi pelajaran. Sehingga dapat disimpulkan bahwa pembelajaran adalah suatu proses belajar yang dibangun guru untuk meningkatkan moral, intelektual, serta mengembangkan berbagai kemampuan yang dimiliki oleh siswa, baik itu 
kemampuan berfikir, kemampuan kreativitas, kemampuan mengkonstruksi pengetahuan, kemampuan pemecahan masalah, hingga kemampuan penguasaan materi pembelajaran dengan baik.

Jihad (2008: 153) tujuan siswa mempelajari matematika, yakni memiliki kemampuan dalam: a ) Menggunakan algoritma (prosedur pekerjaan); b) Melakukan manipulasi secara matematika; c) Mengorganisasi data; d) Memanfaatkan simbol, tabel, diagram dan grafik; e) Mengenal dan menemukan pola; f) Menarik kesimpulan; g) Membuat kalimat atau model matematika; h) Membuat interpretasi bangun dalam bidang dan ruang; i) Memahami pengukuran dan satuan-satuannya; dan j) Menggunakan alat hitung dan alat bantu matematika.

Tujuan mempelajari matematika SMA (Depdiknas dalam Gordah, 2013: 227) adalah agar siswa memiliki kemampuan: (1) memahami konsep matematika, menjelaskan keterkaitan antar konsep dan mengaplikasikan konsep atau algoritma secara luwes, akurat, efisien dan tepat dalam pemecahan masalah,(2) menggunakan penalaran pada pola dan sifat, melakukan manipulasi matematika dalam membuat generalisasi, menyusun bukti, atau menjelaskan gagasan dan pernyataan matematika, (3) memecahkan masalah yang meliputi kemampuan memahami masalah, merencanakan model matematika, menyelesaikan model dan menafsirkan solusi yang diperoleh, (4) mengomunikasikan gagasan dengan simbol, tabel, diagram, atau media lain untuk memperjelas keadaan atau masalah dan (5) memiliki sikap menghargai kegunaan matematika dalam kehidupan.

Tujuan tersebut menunjukkan betapa pentingnya belajar matematika, karena dengan belajar matematika sejumlah kemampuan dan keterampilan tertentu berguna tidak hanya dalam saat belajar matematika namun juga dapat diaplikasikan dalam menyelesaikan berbagai permasalahan dalam kehidupan sehari-hari. Kemampuan komunikasi matematis merupakan salah satu kemampuan yang penting dalam pembelajaran matematika, diantaranya adalah jika proses komunikasi yang terjalin dengan baik maka dapat membantu siswa membangun pemahamannya terhadap ide-ide matematika dan membuatnya menjadi lebih mudah dipahami (Mahmudi, 2009: 7).

Sedangkan menurut pendapat Baroody (dalam Umar, 2012: 2), bahwa pembelajaran harus dapat membantu siswa mengkomunikasikan ide matematika melalui lima aspek komunikasi yaitu representing, listening, reading, discussing dan writing. Selanjutnya disebutkan sedikitnya ada dua alasan penting, mengapa komunikasi dalam pembelajaran matematika perlu ditumbuhkembangkan di kalangan siswa yaitu pertama, mathematics as language dan yang kedua, mathematics learning as social activity.

Pengungkapan pentingnya komunikasi dalam pembelajaran matematika, dapat ditemukan pula dalam berbagai buku pelajaran matematika di Amerika Serikat. Misalnya, dalam buku Connected Mathematics dituliskan bahwa The Overarching Goal of Connected Mathematics adalah "All students should be able to reason and communicate proficiently in mathematics" (Lappan dalam Umar, 2012: 3).Sedangkan dalam buku Mathematics: Applications and Connections disebutkansalah satu tujuan yang ingin dicapai adalah memberikan kesempatan seluas-luasnya kepada para siswa untuk mengembangkan dan mengintegrasikanketerampilan berkomunikasi melalui 
Anugrah Mulia Tampubolon: Peningkatan Kemampuan Komunikasi Matematis Siswa dengan Menggunakan Model Pembelajaran Berbasis Masalah di Kelas X MAN 4 Martubung Medan

modeling, speaking, writing, talking, drawing, serta mempresentasikan apa yang telah dipelajari (Collins dalam Umar, 2012: 3).

Menurut Asikin (dalam Darkasyi: 2014 : 25-26) uraian tentang peran penting komunikasi dalam pembelajaran matematika dideskripsikan sebagai berikut:

1. Komunikasi dimana ide matematika dieksploitasi dalam berbagai perspektif, membantu mempertajam cara berpikir siswa dan mempertajam kemampuan siswa dalam melihat berbagai keterkaitan materi matematika.

2. Komunikasi merupakan alat untuk "mengukur" pertumbuhan pemahaman; dan merefleksikan pemahaman matematika para siswa.

3. Melalui komunikasi, siswa dapat mengorganisasikan dan mengkonsolidasikan pemikiran matematika mereka.

Komunikasi matematika perlu menjadi fokus perhatian dalam pembelajaran matematika, sebab melalui komunikasi, siswa dapat mengorganisasi dan mengkonsolidasi berpikir matematisnya dan siswa dapat meng'explore' ide-ide matematika.

Untuk mengukur kemampuan komunikasi matematis siswa dibutuhkan beberapa indikator yang dikemukakan oleh Sumarmo (dalam Husna 2013 : 85), antara lain: (1) menghubungkan benda nyata, gambar dan diagram ke dalam ide matematika, (2) menjelaskan ide, situasi dan relasi matematika secara lisan atau tulisan dengan benda nyata, gambar, grafik atau bentuk aljabar, (3) menyatakan peristiwa sehari-hari dalam bahasa atau simbol matematika, (4) mendengarkan, berdiskusi dan menulis tentang matematika, (5) membaca presentasi matematika tertulis dan menyusun pertanyaan yang relevan, (6) membuat konjektur, menyusun argumen, merumuskan definisi dan generalisasi.

Dalam rangka meningkatkan kemampuan komunikasi matematis, maka diperlukan suatu model pembelajaran yang dapat meningkatkan kemampuan komunikasi matematis siswa dalam pembelajaran matematika.

Salah satu upaya yang dapat dilakukanadalah dengan menerapkan model pembelajaran berbasis masalah. Pembelajaran berbasis masalah dapat diterapkan pada pembelajaran matematika untuk meningkatkan kemampuan komunikasi matematis siswa. Menurut Sanjaya (2008: 214), pembelajaran berbasis masalah diartikan sebagai rangkaian aktivitas pembelajaran yang menekankan kepada proses penyelesaian masalah secara ilmiah. Sementara Wena (2009: 91) menyebutkan bahwa pembelajaran berbasis masalah merupakan pembelajaran yang menghadapkan siswa pada permasalahan-permasalahan praktis sebagai pijakan dalam belajar atau dengan kata lain siswa belajar melalui permasalahan. Pembelajaran berbasis masalah merupakan pendekatan yang efektif untuk proses berpikir tingkat tinggi (high order thinking). Pembelajaran ini membantu peserta didik untuk memeroses informasi yang telah jadi dalam benaknya dan menyusun pengetahuan mereka sendiri tentang dunia sosial dan sekitarnya. Pembelajaran ini cocok untuk mengembangkan pengetahuan dasar maupun kompleks (Trianto, 2010:92).

Savoie dan Hughes yang dikutip dalam Wena (2009: 91), menyatakan bahwa model pembelajaran berbasis masalah memiliki beberapa karakteristik antara lain sebagai berikut: 
1. Belajar dimulai dengan suatu permasalahan;

2. Permasalahan yang diberikan harus berhubungan dengan dunia nyata siswa;

3. Mengorganisasikan pembelajaran di seputar permasalahan, bukan di seputar disiplin ilmu;

4. Memberikan tanggung jawab yang besar dalam membentuk dan menjalankan secara langsung proses belajar mereka sendiri;

5. Menggunakan kelompok kecil;

6. Menuntut siswa untuk mendemonstrasikan apa yang telah dipelajarinya dalam bentuk produk dan kinerja;

Pembelajaran berbasis masalah tidak dirancang untuk membantu guru memberikan informasi sebanyak-banyaknya kepada peserta didik. Pembelajaran berbasis masalah dikembangkan untuk membantu para peserta didik mengembangkan kemampuan intelektualnya, kemampuan berpikir, dan pemecahan masalah yang peserta didik temui dalam kehidupan sehari-hari.

Adapun sintaks dari pembelajaran berbasis masalah(Trianto, 2010: 98) adalah sebagai berikut :

\section{Tabel 1. Sintaks Pembelajaran Berdasarkan Masalah}

\begin{tabular}{|c|l|}
\hline Tahap & \multicolumn{1}{|c|}{ Tingkah Laku Guru } \\
\hline $\begin{array}{c}\text { Tahap-1 } \\
\text { Orientasi siswa pada } \\
\text { masalah }\end{array}$ & $\begin{array}{l}\text { Guru menjelaskan tujuan pembelajaran, menjelaskan } \\
\text { logistik yang dibutuhkan, mengajukan fenomena atau } \\
\text { demonstrasi atau cerita untuk memunculkan masalah, } \\
\text { memotivasi siswa untut terlibat dalam pemecahan } \\
\text { masalah yang dipilih. }\end{array}$ \\
\hline $\begin{array}{c}\text { Mengorganisasi siswa } \\
\text { untuk belajar }\end{array}$ & $\begin{array}{l}\text { Guru membantu siswa untuk mendefinisikan dan } \\
\text { mengorganisasikan tugas belajar yang berhubungan } \\
\text { dengan masalah tersebut. }\end{array}$ \\
\hline $\begin{array}{c}\text { Tahap-3 } \\
\text { penyelidikan } \\
\text { individual maupun } \\
\text { kelompok }\end{array}$ & $\begin{array}{l}\text { Guru mendorong siswa untuk mengumpulkan } \\
\text { informasi yang sesuai, melaksanakan eksperimen } \\
\text { untuk mendapatkan penjelasan dan pemecahan } \\
\text { masalah. }\end{array}$ \\
\hline $\begin{array}{c}\text { Tahap-4 } \\
\text { Mengembangkan dan } \\
\text { menyajikan hasil } \\
\text { karya }\end{array}$ & $\begin{array}{l}\text { Guru membantu siswa dalam merencanakan dan } \\
\text { menyiapkan karya yang sesuai seperti laporan, video, } \\
\text { dan model serta membantu mereka berbagi tugas } \\
\text { dengan temannya. }\end{array}$ \\
\hline $\begin{array}{c}\text { Tahap-5 } \\
\text { Menganalisis dan } \\
\text { pemgevaluasi proses }\end{array}$ & $\begin{array}{l}\text { Guru membantu siswa untuk melakukan refeleksi } \\
\text { atau evaluasi terhadap penyelidikan mereka dan } \\
\text { proses-proses yang mereka gunakan. }\end{array}$ \\
\hline
\end{tabular}


Anugrah Mulia Tampubolon: Peningkatan Kemampuan Komunikasi Matematis Siswa dengan Menggunakan Model Pembelajaran Berbasis Masalah di Kelas X MAN 4 Martubung Medan

Pada proses pembelajaran matematika di kelas, siswa laki-laki dan siswa perempuan mengikuti proses pembelajaran dengan bermakna. Dalam hal ini, dikenal istilah gender yaitu siswa laki-laki dan perempuan yang sedang mengikuti pelajaran di kelas. Gender di dalam kelas kurang mendapat perhatian, karena metode mengajar guru belum tentu sesuai dengan karakteristik dari gender, serta pemilihan metode mengajar yang digunakan oleh guru masih kurang. Hasil observasi yang dilakukan di lapangan menunjukkan bahwa siswa laki-laki malas menuliskan informasi penting yang diberikan oleh gurunya.

Goos (dalam Prayitno, 2013: 567) menyebutkan bahwa banyak hasil penelitian terkini yang menyajikan adanya perbedaan prestasi belajar, sikap, dan partisipasi yang dipengaruhi perbedaan gender. Para peneliti saat ini menyadari bahwa perbedaan hasil belajar matematika siswa yang dipengaruhi perbedaan gender adalah tidak mutlak, sering tertukar, hal ini juga dipengaruhi latar belakang sosial ekonominya. Hasil penelitian Dewi (dalam Prayitno, 2013: 567) menyimpulkan bahwa kelengkapan komunikasi matematis mahasiswa perempuan lebih baik dibanding mahasiswa laki-laki, namun keakuratan komunikasi matematis mahasiswa laki-laki lebih baik dibandingkan mahasiswa perempuan. Di samping itu, komunikasi lisan mahasiswa perempuan lebih baik dibanding mahasiswa laki-laki, kecuali pada mahasiswa yang berkemampuan matematika tinggi.

Penelitian ini bertujuan untuk (1) meningkatkan kemampuan komunikasi matematis siswa dengan menggunakan model pembelajaran berbasis masalah dan (2) Untuk Mengetahui apakah terdapat interaksi antara pembelajaran berbasis masalah dengan gender terhadap kemampuan komunikasi matematis siswa.

Berdasarkan penjelasan di atas, peneliti merasa perlu untuk mengadakan penelitian tentang penerapan model pembelajaran berbasis masalah yang diperkirakan dapat meningkatan kemampuan komunikasi matematis siswa, sebab dalam pembelajaran ini dimulai dengan melakukan pemecahan masalah yang mendorong siswa untuk aktif dalam melakukan penyeledikan dan penemuan.

\section{B. Metode Penelitian}

Penelitian ini dilaksanakan di MAN 4 Martubung Medan pada Tahun Pelajaran 2014/2015. Subjek penelitian ini adalah siswa kelas X-IPA-2 dan X IPA 4. Penelitian ini dikategorikan ke dalam penelitian eksperimen semu (quasy experiment). Rancangan yang digunakan dalam penelitian ini meliputi tiga tahapan, yaitu: (1) Tahap pengembangan perangkat pembelajaran dan instrumen penelitian, (2) Tahap uji coba perangkat pembelajaran dan instrumen penelitian, (3) Tahap pelaksanaan eksperimen. Setiap tahapan dirancang sedemikian sehingga diperoleh data yang valid sesuai dengan karakteristik variabel sesuai dengan tujuan penelitian.

Rancangan penelitian yang digunakan dalam penelitian ini adalah Pretest Posttest Control Group Design. Dalam rancangan ini terdapat dua kelompok yang dipilih secara random dari sekolah, kemudian diberi pretest untuk mengetahui sejauh mana kesiapan siswa menerima pembelajaran pada materi pokokStatistik dan untuk mengetahui apakah kemampuan sesuai atau tidak, maka dilakukan tes 
awal (pretest). Teknik pengumpulan data yang digunakan dalam penelitian ini adalah: (1) lembar validasi dan (2) instrumen tes kemampuan komunikasi matematis.

Data yang akan dianalisis dalam penelitian ini adalah skor kemampuan komunikasi matematis. Data yang diperoleh dari skor kemampuan komunikasi matematis siswa terhadap matematika dikelompokkan menurut kelompok pembelajaran (PBL, biasa) dan gender (laki-laki, perempuan). Pengolahan data diawali dengan menguji persyaratan statistik yang diperlukan sebagai dasar dalam pengujian hipotesis, antara lain adalah uji normalitas data dan uji homogenitas varians. Selanjutnya, dilakukan uji-t untuk mengetahui peningkatan kemempuan komunikasi matematisdan self efficacy siswa serta analisis varians (ANAVA) dua jalur untukmelihat interakasinya. Seluruh perhitungan statistik menggunakan bantuan program komputer SPSS 17.

\section{Hasil dan Pembahasan}

Untuk menjawab pertanyaan-pertanyaan penelitian yang dikemukakan pada bagian pendahuluan, diperlukan adanya analisis dan interpretasi data hasil penelitian. Analisis yang dimaksud adalah untuk mengetahui peningkatan kemampuan komunikasi matematis siswa pada materi statistika yang memperoleh pembelajaran dengan model berbeda. Kelas eksperimen memperoleh pembelajaran dengan model pembelajaran berbasis masalah (PBM), sedangkan kelas kontrol memperoleh pembelajaran dengan pembelajaran biasa. Selanjutnya akan dilihat pula interaksi antara pembelajaran (PBM dan biasa) dengan gender(laki-laki dan perempuan) terhadap peningkatan kemampuan komunikasi matematis.

Tes kemampuan komunikasi matematis dilakukan dua kali yaitu uji awal (pretest) dan uji akhir (post test) dengan jenis soal yang ekuivalen. Tes awal dan tes akhir diikuti 35 siswa untuk masing-masing kelas. Dengan demikian, dalam analisis data yang menjadi subyek penelitian ini adalah 35 siswa yaitu, yang mengikuti tes awal (pre test) dan tes akhir (post test).Simpangan baku pre test siswa dalam kemampuan komunikasi untuk kelompok eksperimen $(1,245)$ lebih rendah dibanding simpangan baku pre testkomunikasi matematis untuk kelompok kontrol $(1,606)$. Sedangkan simpangan baku post test siswa dalam kemampuan komunikasi matematis untuk kelompok eksperimen $(1,706)$ lebih tinggi dibanding simpangan baku post test siswa kelompok kontrol $(1,576)$. Hal ini berarti bahwa skor pre test dan skor post test kemampuan komunikasi matematis untuk kelompok eksperimenmengalami penyebaran daripada skor pre test dan skor post test untuk kelompok kontrol.

Skor minimum dan skor maksimum data kelompok eksperimen lebih tinggi daripada skor minimum dan skor maksimum data kelompok kontrol.Simpangan baku skor $\mathrm{N}$-Gain kemampuan komunikasi matematis siswa kelompok eksperimen lebih tinggi dari kelas kontrol, artinya skor $\mathrm{N}$-Gain kemampuan komunikasi matematis siswa kelompok eksperimen lebih menyebar daripada skor $\mathrm{N}$-Gain kemampuan komunikasi matematis siswa kelompok kontrol.Rerata gain kemampuan komunikasi matematis siswa pada kelas eksperimen $(0,529)$ terlihat lebih tinggi dibandingkan dengan rerata gain 
Anugrah Mulia Tampubolon: Peningkatan Kemampuan Komunikasi Matematis Siswa dengan Menggunakan Model Pembelajaran Berbasis Masalah di Kelas X MAN 4 Martubung Medan

kemampuan komunikasi matematis yang diberi pembelajaran biasa $(0,406)$. Sedangkan simpangan baku skor $N$-Gain kelompok eksperimen dan skor $N$-Gain kelompok kontrol tidak berbeda jauh, yaitu berturut-turut 0,133 dan 0,128.

Hasil Pengujian Hipotesis Penelitian Kemampuan Komunikasi Matematis Siswa disajikan dalam tabel berikut :

Tabel. 2

Rangkuman Hasil Pengujian Hipotesis Penelitian Kemampuan Komunikasi Matematis Siswa pada Taraf Signifikan 5\%

\begin{tabular}{|c|l|c|l|}
\hline No & \multicolumn{1}{|c|}{ Hipotesis Penelitian } & $\begin{array}{c}\text { Pengujian } \\
\mathbf{H}_{\mathbf{1}}\end{array}$ & \multicolumn{1}{|c|}{ Hasil Pengujian } \\
\hline 1 & $\begin{array}{l}\text { Peningkatan } \\
\text { kemampuankomunikasi } \\
\text { matematis siswa yang } \\
\text { memperoleh PBM lebih tinggi } \\
\text { daripada kemampuan } \\
\text { komunikasi matematis siswa } \\
\text { yang memperoleh } \\
\text { pembelajaran biasa. }\end{array}$ & Diterima & $\begin{array}{l}\text { Peningkatan } \\
\text { kemampuankomunikasi } \\
\text { matematissiswa yang } \\
\text { memperoleh PBM lebih } \\
\text { tinggi daripada kemampuan } \\
\text { komunikasi matematis siswa } \\
\text { yang memperoleh } \\
\text { pembelajaran biasa. }\end{array}$ \\
\hline 2 & $\begin{array}{l}\text { Terdapat interaksi antara } \\
\text { pembelajaran dengan gender } \\
\text { siswa terhadap peningkatan } \\
\text { kemampuan komunikasi } \\
\text { matematis siswa }\end{array}$ & Ditolak & $\begin{array}{l}\text { Tidak terdapat interaksi } \\
\text { antara pembelajaran dengan } \\
\text { gender siswa terhadap } \\
\text { peningkatan kemampuan } \\
\text { komunikasi matematis siswa }\end{array}$ \\
\hline
\end{tabular}

\section{Keterbatasan Penelitian}

Dalam penelitian ini terdapat ketebatasan yang diharapkan akan membuka kesempatan bagi peneliti lainnya untuk melakukan penelitian sejenis yang berguna bagi perluasan ilmu pendidikan. Diantara keterbatasan itu adalah:

1. Instrumen penelitian yang digunakan hanya mengukur kemampuan komunikasi matematis siswa pada materi statistika. Namun, belum dapat mengukur proses pembelajaran yang dilakukan siswa untuk mendapatkan hasil belajar secara keseluruhan. Untuk itu, penelitian ini dapat digabung dengan penelitian yang lebih mendalam melalui penelitian kualitatif sehingga proses belajar siswa dapat diperoleh dengan baik.

2. Data kemampuan komunikasi matematis diperoleh dengan menggunakan tes kemampuan komunikasi matematisyang berbentuk uraian. Kelemahan pengukuran dengan tes uraian adalah jumlah tes yang terbatas, sehingga cakupan materi hanya bersifat mendasar saja. Dikhawatirkan belum mampu menggambarkan kemampuan komunikasi matematis siswa secara keseluruhan.

3. Pada saat pelaksanaan diskusi kelompok, pada awal pembelajaran peneliti sebagai pengajar harus berusaha memotivasi siswa agar kegiatan diskusi berjalan efektif dan lancar. Pada awalnya, siswa masih belum terbiasa 
dengan diskusi kelompok dalam mengerjakan tugas LKS. Hal ini disebabkan karena siswa sudah terbiasa memperoleh pembelajaran biasa, yaitu guru menjelaskan secara rinci tiap materi. Untuk mengatasi hal ini, peneliti memberikan pengarahan/bimbingan kepada siswa yang pandai di dalam kelompoknya untuk mengatur jalannya diskusi dan memotivasi siswa lain untuk aktif memberikan pendapat yang relevan dengan materi yang sedang dipelajari.

4. Dalam peningkatan kemampuan komunikasi matematis siswa, peneliti belum mampu meningkatkan secara signifikan disemua indikator kemampuan komunikasi matematis.

5. Masih banyak faktor-faktor yang tidak diikutsertakan dalam penelitian ini yang diakibatkan oleh keterbatasan waktu dan biaya, seperti faktor sikap dan minat belajar siswa, latar belakang ekonomi keluarga siswa, kompetensi guru baik dalam penguasaan materi maupun dalam mengelola kelas dan lain sebagainya. Sehingga penelitian mengenai kemampuan komunikasi matematis siswa tidak semata-mata dipengaruhi oleh model pembelajaran dan gender siswa.

\section{E. Kesimpulan}

1. Peningkatan kemampuan komunikasi matematis siswa yang memperoleh PBM lebih tinggi daripada kemampuan komunikasi matematis siswa yang memperoleh pembelajaran biasa.Pada kelas eksperimen, peningkatan kemampuan komunikasi matematis terbesar terletak pada indikator menyajikan pernyataan matematika ke dalam bentuk tabel $(0,83)$, sedangkan pada kelas kontrol, peningkatan yang paling besarterjadi pada indikator membaca dan menafsirkan data dalam bentuk diagram ke dalam ide matematika yaitu $(0,62)$.

2. Tidak terdapat interaksi antara pembelajaran dengangender siswa terhadap peningkatan kemampuan komunikasi matematis siswa. Hal ini juga diartikan bahwa interaksi antara pembelajaran (PBM dan Pembelajaran Biasa) dengan gender siswa (laki-laki, perempuan) tidak memberikan pengaruh secara bersama-sama yang signifikan terhadap peningkatan kemampuan komunikasi matematis siswa. Perbedaan peningkatan kemampuan komunikasi matematis siswa disebabkan oleh perbedaan pembelajaran yang digunakan bukan karena gender siswa.

\section{DAFTAR PUSTAKA}

Darkasyi, Muhammad, Rahmah Johar, Anizar Ahmad. 2011. Peningkatan Kemampuan Komunikasi Matematis dan Motivasi Siswa dengan Pembelajaran Pendekatan Quantum Learning pada Siswa SMP Negeri 5 Lhokseumawe. Jurnal Didaktik Matematika. ISSN : 2355-4185. 
Anugrah Mulia Tampubolon: Peningkatan Kemampuan Komunikasi Matematis Siswa dengan Menggunakan Model Pembelajaran Berbasis Masalah di Kelas X MAN 4 Martubung Medan

Gordah, Eka Kasah dan Reni Astuti. 2013. Meningkatkan Kemampuan Komunikasi Matematis Siswa Melalui Pengembangan Bahan Ajar Geometri Dasar Berbasis Model Recipcoral Teaching di STKIP PGRI Pontianak. Prosiding dalam Seminar Nasional Matematika dan Pendidikan Matematika

Jihad, Asep. 2008. Pengembangan Kurikulum Matematika (Tinjauan Teoritisdan Historis). Yogyakarta : Multi Pressindo.

Mahmudi, Ali. 2009. Komunikasi dalam Pembelajaran Matematika. Jurnal MIPMIPA UNHALO 2 (1): 1.

Nata, Abuddin. 2009. Perspektif Islam tentang Strategi Pembelajaran. Kencana: Jakarta.

Sagala, Syaiful. 2009. Konsep dan Makna Pembelajaran. Bandung: ALFABETA.

Sanjaya, Wina. 2008. Strategi Pembelajaran Berorientasi Standar Proses Pendidikan. Jakarta: Kencana.

Trianto. 2010. Mendesain Model Pembelajaran Inovatif Progresif. Jakarta : Kencana.

Umar, Wahid. 2012. Membangun Kemampuan Komunikasi Matematis dalam Pembelajaran Matematika. Jurnal Ilmiah Program Studi Matematika STKIP Siliwangi Bandung(Infinity) Vol 1, No.1.

Usna, M. Ikhsan2, Siti Fatimah3. 2013. Peningkatan Kemampuan Pemecahan Masalah dan Komunikasi Matematis Siswa Sekolah Menengah Pertama Melalui Model Pembelajaran Kooperatif Tipe Think-Pair-Share (TPS). Jurnal Peluang, Volume 1, Nomor 2, ISSN: 2302-5158.

Wena, Made. 2009. Strategi Pembelajaran Inovatif Kontemporer; Suatu Tinjauan Konseptual Operasional. Jakarta : Bumi Aksara. 